\title{
The Effects of Student Led Conferences on the Improvement of 21st Century Career and Life Skills
}

\author{
Canan Şişman and Elif Bahadır \\ Yıldiz Technical University, İstanbul, Turkey \\ https://orcid.org/0000-0001-5414-9757 \\ https://orcid.org/0000-0002-1154-5853
}

\begin{abstract}
This study examined the contribution of student-led conferences to students 'acquisition of responsibility, self-management, self-expression, communication skills and leadership qualities, which are within the scope of 21st century life and career skills. For this purpose, the case study design was used in the study in which a total of 249 students, 280 parents and 22 teachers from primary school (4th grade), secondary school and high school levels in a private school participated. Data triangulation method was used to increase the validity of the research. In this context, the techniques of questionnaire, semi-structured interview and document review were used. Research findings have shown that studentled conferences have a positive effect on helping students acquire 21st century skills, and confirm that this is an important process for student development. In the future research, it can be focused on the effects of these student-led conferences on student achievement. The effects of the portfolio presentations made by the students at the conferences and the planning they made about learning goals at the conferences on their academic success in the long term can be investigated.
\end{abstract}

Keywords: student led conferences; 21st century skills; parent involvement; collaborative education

\section{Introduction}

As the different skills expected from students are added to today's conception of education, determining students' demands, needs, fields of interest and future goals has become more important in student-centered education. Nowadays when the goals of education differ, the cooperation of the school and the parent, which directly or indirectly interact with each other, is inevitable, because it is difficult to separate clearly their responsibilities begin and end. For this reason, schools have started to develop systems that will enrich school-parent cooperation since the 1980s. 
A positive communication between the student, parent and teacher can only be achieved by discussing the student's development and problems and identifying their problems and needs. The most important source of providing this communication is efficient and functional school-parent conferences. These conferences gain students the idea of their being responsible for their own success by giving them the leadership and responsibility they need. Some study findings indicate that parent-teacher conferences are not efficient and functional.

There are many studies conducted in order to determine the contribution of school-parent cooperation in education (Guyton \& Fielstein, 1989; Epstein, 1995; Hackmann, 1997; Davies, 2001; Borba \& Olvera, 2001; Bailey \& Guskey, 2001). These studies mention the positive contributions of school-parent cooperation to many factors including academic success. Among these studies, the most spectacular and closely related to the research is the study by Epstein (1995). Epstein started with practices consisting of certain frameworks defined as "parent involve-

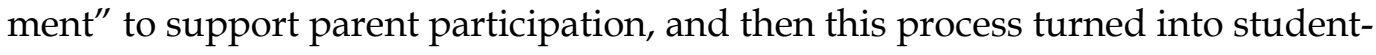
led conferences where students present their work and lead conferences. Studies have shown that student-led conferences support student success and contribute to qualifications such as leadership, social and cultural knowledge (Monroe, 2009). These conferences have enabled students to actively participate in the evaluation of their academic progress, thus, encouraging them to think in order to improve their learning, and to directly share their learning experiences with their teachers and their parents (Borba \& Olvera, 2001). However, with the student-led conferences, students have become more visible and open to the communication environment (Tholander, 2011).

Today, when it comes to student-centered education, classroom practices and process evaluations applied to student products in alternative evaluations, it is an undeniable fact that the importance of student-led parent conferences is obvious. However, in a system where student-centered education is mentioned so much, it is seen that there is not much effort spent in transition to student participated conferences. Whereas, students and parents' active involvement in all stages of education, especially in topics that concern students themselves, is a requirement of student-centered education and, more importantly, democratic education.When the existing curricula in our country are examined, it is seen that such planned conferences are not included.

These conferences are functional and beneficial in many ways, from discussing the student's development, problems and needs one by one, to sharing classroom activities with her/his parents. It is thought that the conferences with student participation are beneficial to bring functionality to the existing parent-teacher conferences as well as enabling students to be a part of the process evaluation. Student-led conferences are also important for that the parents know their students and participate in a part of the school life through these conferences. Organizing the school-parent conferences as teacher-student-parent conferences and including the planned teacher-student-parent conferences in the guidance dimension in education programs are important in terms of student success, teacher and student motivation as well as qualified parent support. These conferences can add 
functionality to existing parent-teacher conferences, enabling parents to be a part of the school system. To include students in the process of being an active part of the system, and to reveal young people's full potential as adults; Students need to master the subjects they have learned at school and to develop their application skills. In addition, business world and political leaders expect from schools to develop "21st century skills" such as problem solving, critical thinking, communication, collaboration and self-management (NRC, 2012).

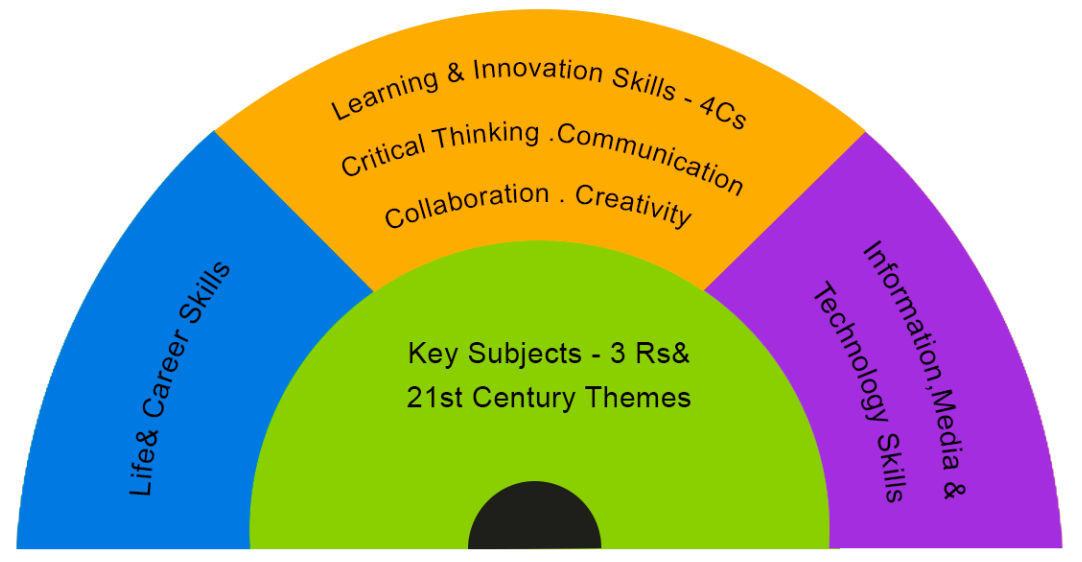

Figure 1: General Framework of 21st Century Skills (P21, 2019)

The general framework of 21st century skills referred to as P21 in the literature is shown in Figure 1. Life and career skills shown in the table as follows; (i) flexibility and adaptability, (ii) initiative and self-management, (iii) social and cross-cultural interaction, (iv) productivity and accountability, and (v) leadership and taking responsibility skills (Trilling \& Fadel, 2009; P21, 2019).

(i) Adaptability; Being adaptive to different roles, job responsibilities, plans and working effectively in uncertain or changing environmental conditions; being flexible and having a positive attitude to praise, failure and criticism, (ii) initiative and self-management; Being able to determine goals with tangible and intangible success criteria, balance long and short-term goals, use time correctly, manage workload effectively, work independently, discover own learning opportunities, look at past experiences with a critical approach for future processes, (iii) social and cross-cultural communication; knowing when to talk and when to listen and being able to control the process (iv) productivity and accountability; being able to work in a planned way to achieve goals even against obstacles and rival pressures, to effectively manage time and targeted aims, (v) leadership and taking responsibility; being able to lead and guide others in order to achieve common goals, by acting in accordance with the principles of honesty and ethics in the use of influence and power, and to be responsible to others (Partnership for 21st Century Learning, 2019).

When looking at the goals of student-led conferences, it can be clearly seen that they support the development of these skills. Some of the goals of these conferences are as follows; it enables students to take a lead role in these conferences, to accept their personal responsibilities in their learning, it teaches students the self- 
evaluation process, it helps students be organized and develop their verbal communication skills, it increases their self-reliance, it encourages students to establish an open and honest communication with their family and teachers, and it engages students in self-reflection, making them more aware of their strengths and weaknesses (Guyton \& Fielstein, 1989; Hackmann, 1997; Bailey \& Guskey, 2001; Davies, 2001).

In addition, that traditional parent conferences started to lose their function, participation in these conferences decreased, and students' opinions were not taken because they were not actively involved in the conferences in which they evaluate their own learning process as a stakeholder, causes a negative effect on the establishment of the needed cooperation and makes it necessary to make parent conferences more functional. The necessity of making the conferences more functional and the necessity of students' taking responsibility for this process by participating in their own educational processes created the need for this research. According to Williams (2020) student progress and prepared students to share their achievement during a Student-Led Conference and Bailey and Guskey (2001) state the benefit of this practice is that SLC requires students to take most of the responsibility for reporting what they have learned.

Trilling and Fadel (2009) states that learning has the potential to increase significantly when students engage in activities through problems in daily life. Therefore, the need for other forms of teaching materials used to achieve learning activities that are in accordance with the curriculum and learning in the 21st century. Based on the presentation of problems related to the conditions of teaching materials used in classroom qualitative research is aimed at analyzing the need to develop teaching materials to improve skills critical thinking of 21 st century students.

When all these elements are taken into account, the student-attended parent conferences take an active role in many subjects from student motivation to parentstudent relationship and from academic success to developing 21st century skills. Considering these issues, it is seen that there are many dimensions of the works to be performed for the student-attended parent conferences and it will be a right tendency to demand these studies. Increasing these studies and examining student and parent tendencies will contribute to the educational literature and applications, therefore, we think that this study is contemporary because it aims to examine the contributions of self-management, leadership, taking responsibility and communication skills that are from the 21st century life and career skills; and it is also unique because it will contribute to parent-school-student cooperation with a different initiative. Within the framework of all these aims, we believe that the effects and impressions of the research conducted with different grade levels on students, parents and teachers will contribute to the studies to be conducted about this subject. The research is being carried out by current researchers as a continuation of this study by deepening the research and examining the process effects. 21st century life and career skills are the skills that we wish our students to acquire, but these skills include processes that the student should realize by being 
aware of along with the parent-school cooperation. Many benefits have been described for SCL, which are categorized in (Laal et al., 2012) article to 4 main groups of: social, psychological, academic and assessment.

Chalkiadaki (2018) concern that special attention should be paid to the maintenance of an equilibrium between the personal and social needs of the individuals and their result-oriented skill development mostly related to professional achievement, especially in the context of the primary education.

By considering all these aims, the research problem was determined as: "What are the opinions of parents, teachers and students about the contribution of studentled conferences to students' acquisitions of the skills of taking responsibility, selfmanagement, self-expression, communication, and leadership qualities that are within the scope of 21st century life and career skills?"

\section{Method}

In this study, the case study design, which is one of the qualitative research designs, was used. Case study is a comprehensive research strategy that mainly qualitative but also uses quantitative data and allows researchers to retain the holistic and meaningful characteristics of real life events (Yin, 2002). In order to increase the validity of the research, data triangulation was used. In this context, data were obtained using the techniques of questionnaire, semi-structured interview and document analysis. In order to increase the reliability of the study, expert opinion was taken for the interview forms of students, teachers and parents. While preparing the interview questions, the Test-Retest reliability analysis method was used and the questionnaire form was applied under the same conditions on the same subjects at two different times (every other 4 weeks). The correlation between the observations at two different times, the total score scores and the consistency of each question were evaluated with Pearson-Spearman correlation. The questions below 0.3 were accepted as incompatible questions and were removed from the questionnaire. Correlations were checked for test-re-test for each subscale. The correlation was found to be 0.78 and the questionnaire was decided to be reliable. A pre-application was made with a teacher and a parent regarding the questions asked in the semi-structured interviews, and after making the necessary adjustments, the main interviews were conducted.

\subsection{Participants}

The study group consists of a total of 249 primary school (4th grade), secondary school and high school students and 280 parents, 22 teachers in the first semester of the 2019-2020 academic year in a private school in Büyükçekmece district of Istanbul province. Since grading and exams start from the 4th grade, in some schools in Turkey, the 4th grade is considered as preparation groups from primary school to secondary school and the applications in secondary school also made to these groups. Research participants were determined randomly. In the interviews, 5 parents, 4 teachers and 1 administrator were selected among the teachers and parents participating in the research according to the convenience sampling due to most respondents answered close to average and some respondents did not want to participate in interviews. 
Table 1: Study participants by levels

\begin{tabular}{|l|c|c|c|c|}
\hline Participants & $\begin{array}{c}\text { Primary } \\
\text { School (4th } \\
\text { Grade) }\end{array}$ & $\begin{array}{c}\text { Secondary } \\
\text { School }\end{array}$ & High School & Total \\
\hline Students & 29 & 146 & 74 & 249 \\
\hline Parents & 33 & 143 & 104 & 280 \\
\hline Teachers & \multicolumn{3}{|c|}{552} & 22 \\
\hline Administrator & 22 & 1 \\
\hline Overall & \multicolumn{3}{|c|}{} \\
\hline
\end{tabular}

\subsection{Study Process and Data Collection Tools}

Approximately one month before the student-led conferences were held for the research, students and teachers were informed about the aim, content practices, schedule and implementation stages of the conference. Information letters were also sent to parents. Students were ensured to have prepared for the conference with the portfolio files containing their works they did during the semester and the rehearsals they made with the drama teachers before the conference.

In the research, after the conference, students, teachers and parents expressed their opinions by filling out the 4-Likert type questionnaire form prepared separately for each group. At the preparation stage of the survey questions, it was focused on which skills students could develop together with their stakeholders in their school lives. For this purpose, the survey questions were formed by taking expert opinions under the framework of different themes and these themes were organized within the scope of 21st century skills as taking responsibility, selfmanagement, self-expression, communication skills, leadership." The survey questions were created in a way to cover the evaluations of parents, students and teachers within the framework of the same themes (taking responsibility, selfmanagement, self-expression, communication skills, leadership). Some of the survey questions applied to all groups are shown in Table 2, Table 3 and Table 4.

Table 2: Some of the statements expected to be responded by students in the questionnaires

\begin{tabular}{|c|l|}
\hline 1. & I think I was able to express myself holistically well at the conference. \\
\hline 2. & I realized my personal responsibilities. \\
\hline 3. & I evaluated my studying habits with a more constructive perspective. \\
\hline 4. & I was able to participate in the decision-making process about my education. \\
\hline 5. & $\begin{array}{l}\text { It allowed me to plan what I should do by understanding the role I had to under- } \\
\text { take for my development. }\end{array}$ \\
\hline
\end{tabular}


Table 3: Some of the statements expected to be responded by parents in the questionnaires

1. My child's awareness of what s/he should do for her/his academic success and responsibilities increased.

2. My child was able to demonstrate her/his learning goals.

Table 4: Some of the statements from the teacher questionnaires

\begin{tabular}{|c|l|}
\hline 1. & My students' awareness about their responsibilities increased. \\
\hline 2. & $\begin{array}{l}\text { My students' awareness of what they should do for their academic success } \\
\text { increased. }\end{array}$ \\
\hline 3. & $\begin{array}{l}\text { My students were able to determine what they had to do for their academic } \\
\text { success. }\end{array}$ \\
\hline 4. & I think my students could evaluate themselves objectively. \\
\hline 5. & I learned about the expectations of my students from me. \\
\hline 6. & We were able to determine my student's future learning goals together. \\
\hline
\end{tabular}

The descriptive analysis of the data obtained from the data sources, some of which are given above, was made by using the data analysis program. In addition, teachers' and parents' opinions were included in the study by using semi-structured interviews prepared separately for parents and teachers. Some of the common questions addressed to parents and teachers are shown in Table 5.

Table 5: Some of the common questions addressed to parents and teachers in these interviews

\begin{tabular}{|l|l|}
\hline 1. & What would you have missed if you had not attended this conference? \\
\hline 2. & What do you think distinguishes this conference from other conferences? \\
\hline 3. & $\begin{array}{l}\text { If you were to summarize it in one sentence, what would you say about these con- } \\
\text { ferences? }\end{array}$ \\
\hline
\end{tabular}

The results regarding the evaluation of the survey results applied to all groups participating in the research are explained in the findings section.

\subsection{Analysis and Interpretation of the Data}

The subgoals of the research have been analyzed separately. Content analysis of the data was done. Participants who participated in the semi-structured interview allowed the use of audio recording. Notes were taken for non-verbal statements. The recordings were later turned into a written document. The related chapters of interviews were transcribed verbatim. Teachers and parents' names were coded. The names of the teachers were coded starting from A1 to A4, the names of the parents starting from $\mathrm{B} 1$ to $\mathrm{B} 5$, and the name of the administrator as $\mathrm{C} 1$. 


\section{Findings}

In this study, it was aimed to reveal the opinions of parents, teachers and students about the subject of student-led conferences' providing students 21st century life and career skills such as initiativeness, self-management, taking the lead and responsibility, and social communication. In this section, the findings obtained from the surveys and interviews are included.

In the findings section, the results obtained from the questionnaires and the results obtained from the interviews are given under different headings.

\subsection{Results of Student, Teacher and Parent Questionnaires}

In 4-point Likert-type surveys applied to students, teachers and parents, numbers from 1 to 4 means; $4=$ strongly agree, $3=$ agree, $2=$ disagree, and $1=$ strongly disagree. The results of the surveys conducted for all three groups were found to be significant, the results are given separately for each group below:

\subsubsection{Student Questionnaire Results}

When the results of the student questionnaire were examined, it was seen that students of primary school (4th grade), secondary school and high school had positive opinions about the student-led conferences, and among these levels, primary and secondary school students were more positive than high school students.

The survey questions have been classified and analyzed under the created themes below.

\section{Leadership and Self-Expression}

Table 6: Analysis of the student questionnaires according to the levels of leadership and self-expression skills

\begin{tabular}{|c|c|c|c|c|c|c|c|}
\hline Themes & $\begin{array}{l}\text { Survey } \\
\text { Questions }\end{array}$ & $\begin{array}{l}\text { School } \\
\text { Levels }\end{array}$ & $\mathbf{N}$ & $\underset{\text { um }}{\text { Minim }}$ & $\begin{array}{l}\text { Maxi } \\
\text { mum }\end{array}$ & Mean & $\begin{array}{l}\text { Std. } \\
\text { Devi } \\
\text { ation }\end{array}$ \\
\hline \multirow{4}{*}{$\begin{array}{l}\text { Leadership } \\
\text { and Self-Ex- } \\
\text { pression }\end{array}$} & \multirow{4}{*}{$\begin{array}{l}\text { I think I } \\
\text { could ex- } \\
\text { press my- } \\
\text { self well } \\
\text { holistically } \\
\text { at the con- } \\
\text { ference. }\end{array}$} & Primary & 29 & 2.00 & 4.00 & 3.4483 & 0.63168 \\
\hline & & Secondary & 146 & 2.00 & 4.00 & 3.5959 & 0.51967 \\
\hline & & High & 74 & 1.00 & 4.00 & 3.4865 & 0.60235 \\
\hline & & Total & 249 & 1.00 & 4.00 & 3.5462 & 0.55981 \\
\hline
\end{tabular}

Analysis of the student questionnaires according to the levels of leadership and self-expression skills is shown in Table 6 above. The average of the responses to the item of "I think I could express myself well holistically at the conference." was 3.55 and the students mostly responded this item as "I strongly agree". This shows that the students leading the conferences considered themselves successful in managing the process and expressing themselves well. The results of standart deviation indicate that the participants in the research mostly gave answers close to the average. 


\section{Self-Expression and Communication}

Table 7: Analysis of the student questionnaires according to the levels of self-expression and communication skills

\begin{tabular}{|c|c|c|c|c|c|c|c|}
\hline Themes & $\begin{array}{c}\text { Survey } \\
\text { Questions }\end{array}$ & $\begin{array}{l}\text { School } \\
\text { Levels }\end{array}$ & $\mathbf{N}$ & $\begin{array}{c}\text { Minim } \\
\text { um }\end{array}$ & $\begin{array}{l}\text { Maxi } \\
\text { mum }\end{array}$ & Mean & $\begin{array}{l}\text { Std. } \\
\text { Deviat } \\
\text { ion }\end{array}$ \\
\hline \multirow{8}{*}{$\begin{array}{l}\text { Self-Ex- } \\
\text { pression } \\
\text { and Com- } \\
\text { munica- } \\
\text { tion }\end{array}$} & \multirow{4}{*}{$\begin{array}{l}\text { I have estab- } \\
\text { lished open and } \\
\text { honest commu- } \\
\text { nication with } \\
\text { my family and } \\
\text { teacher. }\end{array}$} & Primary & 29 & 3.00 & 4.00 & 3.7241 & 0.45486 \\
\hline & & Secondary & 146 & 3.00 & 4.00 & 3.7945 & 0.40544 \\
\hline & & High & 74 & 3.00 & 4.00 & 3.8243 & 0.38314 \\
\hline & & Total & 249 & 3.00 & 4.00 & 3.7952 & 0.40438 \\
\hline & \multirow{4}{*}{$\begin{array}{l}\text { I enjoyed ex- } \\
\text { pressing myself } \\
\text { before my par- } \\
\text { ents and my } \\
\text { teacher. }\end{array}$} & Primary & 29 & 2.00 & 4.00 & 3.3793 & 0.67685 \\
\hline & & Secondary & 145 & 1.00 & 4.00 & 3.5931 & 0.65082 \\
\hline & & High & 73 & 2.00 & 4.00 & 3.4942 & 0.64814 \\
\hline & & Total & 247 & 1.00 & 4.00 & 3.5385 & 0.65452 \\
\hline
\end{tabular}

Analysis of the student questionnaires according to the levels of self- expression and communication skills is shown in Table 7 above. The item with the highest average response among the conference items was "I have established open and honest communication with my family and teacher." The average of this item is approximately 3.79. While the average of high school students' responses is 3.82, the average of secondary school students' responses is 3.79 and primary school students' responses is 3.72. The average response to the similar item of "I enjoyed expressing myself before my parents and my teacher." is 3.54. The results of these items indicate that students' self-expression and social communication perceptions are positive and they manage the process with pleasure.

\section{Self-Management and Taking Responsibility}

Table 8: Analysis of the student questionnaires according to the levels of self-management and taking responsibility

\begin{tabular}{|l|l|c|c|c|c|c|c|}
\hline Themes & \multicolumn{1}{|c|}{$\begin{array}{c}\text { Survey } \\
\text { Questions }\end{array}$} & $\begin{array}{c}\text { School } \\
\text { Levels }\end{array}$ & $\mathbf{N}$ & $\begin{array}{c}\text { Mini } \\
\text { mum }\end{array}$ & $\begin{array}{c}\text { Maxim } \\
\text { um }\end{array}$ & Mean & $\begin{array}{c}\text { Std. } \\
\text { Deviation }\end{array}$ \\
\hline $\begin{array}{l}\text { Self- } \\
\text { Manage- } \\
\text { ment and } \\
\text { Taking } \\
\text { Responsi- } \\
\text { bility }\end{array}$ & $\begin{array}{l}\text { It helped me to } \\
\text { strengths and } \\
\text { weaknesses. }\end{array}$ & Primary & 29 & 2.00 & 4.00 & 3.3103 & 0.60376 \\
\cline { 3 - 9 } & & Secondary & 144 & 1.00 & 4.00 & 3.4583 & 0.63549 \\
\cline { 3 - 8 } & & Total & $\mathbf{2 4 7}$ & $\mathbf{1 . 0 0}$ & $\mathbf{4 . 0 0}$ & $\mathbf{3 . 4 0 4 9}$ & $\mathbf{0 . 6 6 7 2 2}$ \\
\cline { 3 - 8 } & & & & & & & \\
\hline
\end{tabular}




\begin{tabular}{|c|c|c|c|c|c|c|}
\hline \multirow{4}{*}{$\begin{array}{l}\text { I realised my } \\
\text { personal re- } \\
\text { sponsibilities. }\end{array}$} & Primary & 28 & 1.00 & 4.00 & 3.5357 & 0.88117 \\
\hline & Secondary & 145 & 1.00 & 4.00 & 3.4069 & 0.71197 \\
\hline & High & 74 & 1.00 & 4.00 & 3.2973 & 0.71634 \\
\hline & Total & 247 & 1.00 & 4.00 & 3.3887 & 0.73443 \\
\hline \multirow{4}{*}{$\begin{array}{l}\text { I evaluated my } \\
\text { study habits } \\
\text { more } \\
\text { constructively. }\end{array}$} & Primary & 28 & 3.00 & 4.00 & 3.6071 & 0.49735 \\
\hline & Secondary & 143 & 2.00 & 4.00 & 3.5455 & 0.59015 \\
\hline & High & 74 & 1.00 & 4.00 & 3.4324 & 0.66376 \\
\hline & Total & 245 & 1.00 & 4.00 & 3.5184 & 0.60452 \\
\hline \multirow{4}{*}{$\begin{array}{l}\text { I was able to } \\
\text { participate in } \\
\text { the decision- } \\
\text { making process } \\
\text { about my edu- } \\
\text { cation. }\end{array}$} & Primary & 29 & 1.00 & 4.00 & 3.1724 & 0.96618 \\
\hline & Secondary & 143 & 2.00 & 4.00 & 3.5594 & 0.58889 \\
\hline & High & 74 & 2.00 & 4.00 & 3.4054 & 0.61753 \\
\hline & Total & 246 & 1.00 & 4.00 & 3.4675 & 0.66160 \\
\hline \multirow{4}{*}{$\begin{array}{l}\text { I became aware } \\
\text { of the factors } \\
\text { that prevented } \\
\text { me from } \\
\text { learning and } \\
\text { working } \\
\text { effectively. }\end{array}$} & Primary & 29 & 2.00 & 4.00 & 3.3793 & 0.62185 \\
\hline & Secondary & 145 & 1.00 & 4.00 & 3.4138 & 0.72252 \\
\hline & High & 74 & 1.00 & 4.00 & 3.2838 & 0.71232 \\
\hline & Total & 248 & 1.00 & 4.00 & 3.3710 & 0.70817 \\
\hline
\end{tabular}

Analysis of the student questionnaires according th the levels of self-management and taking responsibility is shown in Table 8 above. The average response for the item of "I realised my personal responsibilities." was 3.38. For this item, while the average of the responses given by high school students was 3.29, it was 3.40 for secondary school students and 3.53 for primary school students. Primary school students generally responded this item as "I strongly agree", while high school students responded it as "I agree." The average response given to the item of "I was able to participate in the decision-making process about my education." was 3.46. In this item, the average response given by high school students was 3.40 and secondary school students responded it as 3.55, while the response given by primary school students was 3.17. This item was the item that had the lowest average of the responses given by primary school students in the whole questionnaire. Other responses given to the survey questions of these themes are shown in Table 3. The average responses given by the students to the items that are about being closely involved with their own educational journey, increasing their awareness of their responsibilities, and managing their own development show us that students' perceptions towards themselves on self-management and taking responsibility skills are positive. 


\section{Leadership and Self-Management}

Table 9: Analysis of the student questionnaires according to the levels of leadership and self-management skills

\begin{tabular}{|c|c|c|c|c|c|c|c|}
\hline Themes & $\begin{array}{c}\text { Survey } \\
\text { Questions }\end{array}$ & Levels & $\mathbf{N}$ & $\underset{\text { um }}{\text { Minim }}$ & $\begin{array}{l}\text { Maxim } \\
\text { um }\end{array}$ & Mean & $\begin{array}{c}\text { Std. } \\
\text { Deviation }\end{array}$ \\
\hline \multirow{4}{*}{$\begin{array}{l}\text { Leader- } \\
\text { ship and } \\
\text { Self-Man- } \\
\text { agement }\end{array}$} & \multirow{4}{*}{$\begin{array}{l}\text { It allowed } \\
\text { me to plan } \\
\text { what I } \\
\text { should do } \\
\text { by under- } \\
\text { standing the } \\
\text { role I had to } \\
\text { undertake } \\
\text { for my de- } \\
\text { velopment. }\end{array}$} & $\begin{array}{l}\text { Primary } \\
\text { School }\end{array}$ & 29 & 2.00 & 4.00 & 3.7241 & 0.52757 \\
\hline & & $\begin{array}{l}\text { Secondary } \\
\text { School }\end{array}$ & 146 & 1.00 & 4.00 & 3.5274 & 0.65596 \\
\hline & & $\begin{array}{l}\text { High } \\
\text { School }\end{array}$ & 74 & 2.00 & 4.00 & 3.3919 & 0.59259 \\
\hline & & Total & 249 & 1.00 & 4.00 & 3.5100 & 0.62934 \\
\hline
\end{tabular}

Analysis of the student questionnaires according to the levels of leadership and self-management skills is shown in Table 9 above. The average response given to the item of "It allowed me to plan what I should do by understanding the role I had to undertake for my development." was 3.51. While the average response given by primary school students to this item was 3.72, it was 3.52 for secondary school students and 3.39 for high school students. In this item, it was observed that the student responses between the levels differed. It is seen that the students' opinions about the leadership in reaching common goals and their determining their own goals and planning these goals in the long and short term are also strongly positive.

\subsubsection{Parent Questionnaire Results}

When the parent questionnaire results are examined, it is seen that the parents gave positive responses to the questionnaire items. Parent questionnaires have been examined under thematic headings below.

\section{Self-Management and Taking Responsibility}

Table 10: Analysis of the parent questionnaires on self-management and responsibility taking skills

\begin{tabular}{|l|l|c|c|c|c|c|}
\hline Themes & Survey Questions & N & $\begin{array}{c}\text { Minim } \\
\text { um }\end{array}$ & $\begin{array}{c}\text { Maximu } \\
\mathbf{m}\end{array}$ & Mean & $\begin{array}{c}\text { Std. } \\
\text { Deviation }\end{array}$ \\
\hline $\begin{array}{l}\text { Self-Man- } \\
\text { agement } \\
\text { and Taking } \\
\text { Responsi- } \\
\text { bility }\end{array}$ & $\begin{array}{l}\text { My child's aware- } \\
\text { ness of what s/he } \\
\text { should do for } \\
\text { her/his academic } \\
\text { success increased. }\end{array}$ & 280 & 2.00 & 4.00 & 3.4357 & 0.57062 \\
\hline
\end{tabular}

Analysis of the parent questionnaires on self-management and responsibility taking skills is shown in Table 10 above. The average response given by the parents for the item of "My child's awareness of what s/he should do for her/his academic success increased." was 3.44. This shows that the parents mostly responded to it as "I agree." 


\section{Leadership and Self-Management}

Table 11: Analysis of the parent questionnaires on leadership and self-management skills

\begin{tabular}{|l|l|c|c|c|c|c|}
\hline \multicolumn{1}{|c|}{ Themes } & \multicolumn{1}{|c|}{$\begin{array}{c}\text { Survey } \\
\text { Questions }\end{array}$} & $\mathbf{N}$ & $\begin{array}{c}\text { Minim } \\
\text { um }\end{array}$ & $\begin{array}{c}\text { Maxim } \\
\text { um }\end{array}$ & Mean & $\begin{array}{c}\text { Std. } \\
\text { Deviation }\end{array}$ \\
\hline $\begin{array}{l}\text { Leadership } \\
\text { and Self-Man- } \\
\text { agement }\end{array}$ & $\begin{array}{l}\text { My child was } \\
\text { able to demon- } \\
\text { strate her/his } \\
\text { learning goals. }\end{array}$ & 276 & 2.00 & 4.00 & 3.4094 & 0.56161 \\
\hline & $\begin{array}{l}\text { I prefer this con- } \\
\text { ference to tradi- } \\
\text { tional parents' } \\
\text { conferences. }\end{array}$ & 275 & 1.00 & 4.00 & 3.3673 & 0.94349 \\
\hline
\end{tabular}

Analysis of the parent questionnaires on leadership and self-management skills is shown in Table 11 above. The average response to the item of "My child was able to demonstrate her/his learning goals." was similarly 3.4. Parents mostly responded to this item as "I agree.". Similarly, they mostly responded as "I agree" to the statement of "I prefer this conference to traditional parents' conferences." This shows that parents find the student-led conferences effective, and they want these conferences to continue.

\subsubsection{Teacher Questionnaire Results}

\section{Self-Expression and Communication Skills}

Table 12: Analysis of the teacher questionnaires on self-expression and communication skills

\begin{tabular}{|c|l|c|c|c|c|c|}
\hline Themes & \multicolumn{1}{|c|}{$\begin{array}{c}\text { Survey } \\
\text { Questions }\end{array}$} & $\mathbf{N}$ & $\begin{array}{c}\text { Minimu } \\
\mathbf{m}\end{array}$ & $\begin{array}{c}\text { Maxim } \\
\text { um }\end{array}$ & Mean & $\begin{array}{c}\text { Std. } \\
\text { Deviation }\end{array}$ \\
\hline $\begin{array}{l}\text { Self-Ex- } \\
\text { pression } \\
\text { and Com- } \\
\text { munica- } \\
\text { tion Skills }\end{array}$ & $\begin{array}{l}\text { My students were } \\
\text { able to express } \\
\text { themselves } \\
\text { clearly and } \\
\text { properly. }\end{array}$ & 22 & 2.00 & 4.00 & 3.2273 & 0.52841 \\
\cline { 2 - 6 } & $\begin{array}{l}\text { I think my stu- } \\
\text { dents could eval- } \\
\text { uate themselves } \\
\text { objectively. }\end{array}$ & 22 & 2.00 & 4.00 & 3.2727 & 0.63109 \\
\hline
\end{tabular}

Analysis of the teacher questionnaires on self-expression and communication skills is shown in Table 12 above. When examining the analysis results of the teacher questionnaires, it was seen that the responses were positive as in the student and parent questionnaires. The average response given by the teachers to the statement of "My students were able to express themselves clearly and properly." was 3.22 and the average of the responses given to the item of "I think my students 
could evaluate themselves objectively." was 3.27. This shows that teachers find their students successful in self-expression and communication skills.

\section{Self-Management and Taking Responsibility}

Table 13: Analysis of the teacher questionnaires on self-management and taking re-

\begin{tabular}{|c|l|c|c|c|c|c|}
\hline Themes & Survey Questions & $\mathbf{N}$ & $\begin{array}{c}\text { Minim } \\
\text { um }\end{array}$ & $\begin{array}{c}\text { Maxim } \\
\text { um }\end{array}$ & Mean & $\begin{array}{c}\text { Std. } \\
\text { Deviation }\end{array}$ \\
\hline $\begin{array}{l}\text { Self-Manage- } \\
\text { ment and } \\
\text { Taking Re- } \\
\text { sponsibility }\end{array}$ & $\begin{array}{l}\text { My students } \\
\text { awareness about } \\
\text { their responsibili- } \\
\text { ties increased. }\end{array}$ & 22 & 2.00 & 4.00 & 3.5000 & 0.59761 \\
\cline { 2 - 7 } & $\begin{array}{l}\text { My students } \\
\text { awareness of what } \\
\text { they should do for } \\
\text { their academic } \\
\text { success increased. }\end{array}$ & 22 & 3.00 & 4.00 & 3.5000 & 0.51177 \\
\cline { 2 - 7 } & $\begin{array}{l}\text { My students were } \\
\text { able to determine } \\
\text { what they had to } \\
\text { do for their aca- } \\
\text { demic success. }\end{array}$ & 22 & 2.00 & 4.00 & 3.3182 & 0.56790 \\
\hline
\end{tabular}

Analysis of the teacher questionnaires on self-management and taking responsibility is shown in Table 13 above. The average of the answers given to the items of "My students' awareness about their responsibilities increased," and "My students' awareness of what they should do for their academic success increased." was 3.5. The teachers mostly responded this item as "I strongly agree." The average of the answers given to the item of "My students were able to determine what they had to do for their academic success." was 3.31. The teachers mostly responded to this item as "I agree". Teachers strongly agree that their students' awareness of what they should do for their academic success and their responsibilities have increased. Besides, although the students expressed positive opinions about determining what they should do at this point, there is not a strong consensus on this item as much as the previous items. This shows that these conferences contribute positively to the skills of self-management and taking responsibility, but the more development of these skills will depend on the repetition of the conferences. 


\section{Leadership and Self-Management}

Table 14: Analysis of the teacher questionnaires on leadership and self-management

\begin{tabular}{|c|l|c|c|c|c|c|}
\hline \multicolumn{1}{|c|}{ Themes } & Survey Questions & $\mathbf{N}$ & $\begin{array}{c}\text { Minim } \\
\text { um }\end{array}$ & $\begin{array}{c}\text { Maxi } \\
\text { mum }\end{array}$ & Mean & $\begin{array}{c}\text { Std. } \\
\text { Deviation }\end{array}$ \\
\hline $\begin{array}{l}\text { Leadership and } \\
\text { Self-Manage- } \\
\text { ment }\end{array}$ & $\begin{array}{l}\text { My students were } \\
\text { able to reveal their } \\
\text { expectations from } \\
\text { their parents and } \\
\text { me. }\end{array}$ & 22 & 2.00 & 4.00 & 3.1818 & 0.73266 \\
\cline { 2 - 6 } & $\begin{array}{l}\text { We were able to de- } \\
\text { termine the future } \\
\text { learning goals of } \\
\text { my student with } \\
\text { her/him. }\end{array}$ & 21 & 2.00 & 4.00 & 3.0952 & 0.70034 \\
\hline & $\begin{array}{l}\text { I prefer this confer- } \\
\text { ence to traditional } \\
\text { parents' confer- } \\
\text { ences. }\end{array}$ & 22 & 1.00 & 4.00 & 3.5909 & 0.95912 \\
\hline
\end{tabular}

Analysis of the teacher questionnaires on leadership and self-management skills is shown in Table 14 above. The average response given to the item of "We were able to determine the future learning goals of my student with her/him." was 3.09 and the average response to the item of "My students were able to reveal their expectations from their parents and me." was 3.18. The teachers mostly answered as "I agree" to these items.

When examining the teacher, parent, and student questionnaires, it is seen that all three groups have very positive opinions about the student-led conferences. The average responses of the three groups are close to each other and positive about the students' increasing their awareness and responsibilities and planning their development processes by constructively evaluating their own educational processes and determining what should be done. In addition, students and teachers expressed positive opinions about students' expressing themselves holistically, clearly and accurately, and evaluating themselves objectively, while it was observed that the students evaluated themselves more positively in these items of the questionnaire than their teachers. It is also seen that the survey results of all three groups are positive and close to each other in terms of the students' being objective in managing the process correctly and evaluating themselves and ensuring an open and honest communication with their family and teachers.

\subsection{Interviews}

In this section, the analysis of the interviews had 5 parents, 4 teachers and 1 principal selected among the parents and teachers according to the convenience sampling who participated in the study, and the analysis of the interviews prepared specifically for conceptual frameworks including communication skills, taking re- 
sponsibility, self-evaluation, self-management and leadership are included. During the interviews, parents and teachers shared their views on the positive effects of student-led conferences on students.

The parents have been asked the question of "Have you observed any differences in your child's ability to manage and take responsibility since the conference? If yes, could you tell us briefly what the differences you think are?" and they have answered that their children's mentioned skills improved. The answer of B1, the parent of the primary school 4th grade student, was as follows:

"My son looked in our eyes at the conference and said, 'My parents don't want me to play football, they want me to play basketball, but I will be a football player.' He expressed himself well about what he wants for football and made us aware of it. He realized his shortcomings and took very good steps forward to correct them."

Similarly, in the interviews with the teachers, the answer given to the question of "Have there been any differences in your student's skills of self-management and taking responsibility since the last conference? If yes, could you please briefly mention what they are?" was positive. High school literature teacher A2,

"It surely happened. After students started to express themselves, this was reflected in their school behaviors. They could say what they wanted and what they needed more clearly and could express their expectations from the school more clearly."

In the interviews, all of the teachers and parents stated that they observed that the student-led conferences made a positive difference in the students' self-management and taking responsibility skills. Similar observations from the two groups show that this positive change in students is reflected in both their in-school and out-of-school behaviors.

The answers given by the parents to the question of "Do you think this conference was effective in using your child's communication skills actively?" were positive. A secondary school student's parent B3 responded as;

"Yes, I do. Personally, if I had not attended this conference, I would not have been able to see my child's self-reliance or how my child was able to maintain his communication with you. I think their leading this conference is important in terms of expressing themselves more easily in public."

B4, parent of another secondary school student answered the question as; "Of course it was. These conferences will be even more effective every time our children attend them."

Teachers generally answered the questions of "Do you think this conference was effective in using your student's communication skills effectively?" as; "I strongly agree." A high school physics teacher A1 responded it as;

"I strongly agree. Some emotional moments were experienced between the two parents and the two students, as if there had not been any communication between them before, and a knot was untied after this conference. 
While the students expressed the most important value in their point of view on life, their parents' reactions were interesting. Obviously, there has not been such a dialogue between them... They noticed the differences between their own perspectives for themselves and their parents' perspectives towards them."

Parents and teachers stated that the conferences held were effective for students to use their communication skills effectively. Additionally, both groups believe that if these conferences continue, these skills will improve more.

Parents answered the question of "Do you think your child was able to evaluate herself/himself constructively and objectively at this conference?" as; "Yes." B1, parent of primary school 4th grade student responded it as;

"My son evaluated himself very well, objectively and ethically. He told me what he didn't do, how he had to improve himself and so on... He was much more objective."

The teachers' response to the question of "Do you think your student was able to evaluate herself/himself constructively and objectively in this conference?" was mostly positive. However, only the high school physics teacher A1 replied it as;

"Some of the students sometimes made too many negative judgments for themselves while trying to be objective."

Both groups stated that the students were objective in evaluating themselves. However, they also stated that some students sometimes made too many judgmental comments about themselves with the concern of being realistic while making this evaluation.

When the parents were asked about the general evaluation of the conference, they stated that they preferred this conference to traditional parent conferences. When asked about the factors that distinguish this conference from other conferences, one of the responses was

"This is the child's participation in his/her own education. S/he makes her/his own decisions, s/he implements her/his own decisions. S/he also explains its results by herself/himself. We are trying to raise children who can express themselves."

When the teachers were asked about the general evaluation of the conference, some of the answers were as follows: High school literature teacher A2 replied it as;

"The positive aspect of this conference is that it enables students to talk about their own learning and to express themselves well."

On the other hand, high school physics teacher A1, responded it as;

"The most positive aspects of the conferences were that there were no hierarchical differences between students, teachers and parents, that the student felt herself/himself at the center in the subjects related to her/him, and that such an opportunity was offered to her/him in order to find more creative solutions for her/his own problems." 
Secondary school principal C1 answered the question as;

"The students felt the need to keep their promises in these conferences.

Parents heard what they did not expect about their children's imaginations, ideals and future expectations."

It is seen in the interviews that parents, administrators and teachers all expressed very positive opinions about the positive effects of student-led conferences on students. Participants consider these conferences as a necessity in the process of raising students who can express themselves well, have a developed sense of responsibility, and who can plan and manage their own development processes.

\section{Discussion and Conclusion}

This research has confirmed that student-led conferences are an important process for student development. Restructuring the applications that have lost their functions at schools in accordance with the 21st century requirements is a must. To be able to grow up as individuals who can express themselves correctly, take the lead, take responsibility, manage themselves, and have developed their inner discipline, education systems should be arranged accordingly. As Wan (2011) stated Steven L. Paines' words in his book: "Teaching our high school students 21st century skills is no longer an option, it is a necessity." Considering all these, it is seen that parents' conferences should be replaced by student-led conferences.

The other important finding is, in the analysis of student questionnaires according to the levels, some items are seen to differ between the levels, although the average responses given to the questionnaire items were positive. One of the items that differed most is that high school students who grew up with traditional parents' conferences, where they did not have a say, agreed less than primary and secondary school students with the statement of "It enabled me to understand the role I have to undertake for my development and to plan what I should do." This situation shows that the system has not provided students with skills such as selfmanagement and leadership up to the present, on the contrary, it has made students dependent on the decisions that teachers and parents will make for themselves. This finding coincides with what Williams, (2020). The findings show that student-led conferences have a quite positive contribution in helping students gain 21st century skills, but the development of these skills also depends on the repetition of these conferences. Students, who will build the future, will develop these skills more in each conference.

\section{Recommendations}

This study aimed to observe the contribution of student-led conferences to 21st century life and career skills of students. In the future research projects, it can be focused on the direct effects of student-led conferences on students' academic success. The effects of the portfolio presentations made by the students at the conferences and the planning they made about learning goals at the conferences on their academic success in the long term can be investigated. 


\section{References}

Bailey, J. M., \& Guskey, T. R. (2001). Implementing student-led conferences. Corwin Press.

Borba, J. A., \& Olvera, C. M. (2001). Student-led parent-teacher conferences. The Clearing House, 74(6), 333-336. https:/ / doi.org/10.1080/00098650109599220

Chalkiadaki, A. (2018). A systematic literature review of 21st century skills and competencies in primary education. International Journal of Instruction, 11(3), 1-16. https:// doi.org/10.12973/iji.2018.1131a

Davies, A. (2001). Involving students in communicating about their learning. Nassp Bulletin, 85(621), 47-52. https://doi.org/10.1177\%2F019263650108562106

Epstein, J. L. (1995). School/family/community partnerships: Caring for the children we share. Phi Delta Kappan, 81-96. https:// doi.org/10.1177/003172171009200326

Guyton, J. M., \& Fielstein, L. L. (1989). Student-led parent conferences: A model for teaching responsibility. Elementary School Guidance \& Counseling, 24(2), 169-172. https://www.jstor.org/stable/42868910

Hackmann, D. G. (1997). Student-Led Conferences at the Middle Level. ERIC Digest. https://eric.ed.gov/?id=ED407171

Laal, M., Laal, M., \& Kermanshahi, Z. K. (2012). 21st century learning; learning in collaboration. Procedia-Social and Behavioral Sciences, 47, 1696-1701. https:// doi.org/10.1016/j.sbspro.2012.06.885

Monroe, T. A. (2009). Empowered Students: A Case Study of Student-led Conferences in Middle Level Education [New Britain: Doctoral dissertation, Central Connecticut State University].

National Research Council (NRC). (2012). Education for life and work: Developing transferable knowledge and skills in the 21st century. National Academies Press.

Partnership for 21st Century Learning A Network of Battelle for Kids (P21). (2019). Frameworks \& Resources. https://www.battelleforkids.org/networks/p21/frameworks-resources

Tholander, M. (2011). Student-led conferencing as democratic practice. Children \& Society, 25(3), 239-250. https:// doi.org/10.1111/j.1099-0860.2009.00277.x

Trilling, B., \& Fadel, C. (2009). 21st century skills: Learning for life in our times. John Wiley \& Sons. http://dx.doi.org/10.14507/er.v0.1296

Wan, G., \& Gut, D. M. (Eds.). (2011). Bringing schools into the 21st century (Vol. 13), (pp. 1). Springer Science \& Business Media.

Williams, C. (2020). Levels Of Feedback In Preparation For A Student-Led Conferencing Event: A Case Study Of Elementary Students' Experiences Theses and Dissertations-- Curriculum and Instruction. 29. https://uknowledge.uky.edu/edc_etds/29

Yin, R. K. (2002). Case study research: Design and methods, applied social research. 3rd Ed in ICSM'00, 1-18. 